Please cite this paper as: Luna, S., Gold, M., Albert, A., Ceccaroni, L., Claramunt, B., Danylo, O., Haklay, M., Kottmann, R., Kyba, C., Piera, J., Radicchi, A., Schade, S., and Sturm, U., 2018. Developing mobile applications for environmental and biodiversity citizen science: considerations and recommendations. In: Joly A., Vrochidis S., Karatzas K., Karppinen A., Bonnet P. (eds) Multimedia Tools and Applications for Environmental \& Biodiversity Informatics. (pp. 9-30) Springer, Cham

\title{
Developing mobile applications for environmental and biodiversity citizen science: considerations and recommendations
}

Soledad Luna, Margaret Gold, Alexandra Albert, Luigi Ceccaroni, Bernat Claramunt, Olha Danylo, Muki Haklay, Renzo Kottmann, Christopher Kyba, Jaume Piera, Antonella Radicchi, Sven Schade, Ulrike Sturm

Soledad Luna, European Citizen Science Association (ECSA), Institute of Forest Growth and Computer Science, Technische Universität Dresden, sluna@institutonazca.org

Margaret Gold, National History Museum London

Alexandra Albert, University of Manchester

Luigi Ceccaroni, 1000001 Labs

Bernat Claramunt, CREAF, Ecology Unit (BABVE)

Olha Danylo, International Institute for Applied Systems Analysis (IIASA)

Muki Haklay, Extreme Citizen Science (ExCiteS), University College London

Renzo Kottmann, Max Planck Institute for marine Microbiology

Christopher Kyba, German Research Centre for Geosciences (GFZ)

Jaume Piera, Institute of Marine Sciences (ICM-CSIC)

Antonella Radicchi, Technical University Berlin

Sven Schade, European Commission, Joint Research Centre (JRC)

Ulrike Sturm, Museum fuer Naturkunde, Leibniz Institute for Research on Evolution and Biodiversity

\begin{abstract}
The functionality available on modern 'smartphone' mobile devices, along with mobile application software and access to the mobile web, have opened up a wide range of ways for volunteers to participate in environmental and biodiversity research by contributing wildlife and environmental observations, geospatial information, and other context-specific and time-bound data. This has brought about an increasing number of mobile phone based citizen science projects that are designed to access these device features (such as the camera, the microphone, and GPS location data), as well as to reach different user groups, over different project durations, and with different aims and goals. In this chapter we outline a number of key considerations when designing and developing mobile applications for citizen science, with regard to (1) interoperability and data standards, (2) participant centred design and agile development, (3) user interface \& user experience design, and (4) motivational factors for participation.
\end{abstract}

Key words: Mobile Apps citizen science Metadata data standard re-use

\section{Introduction}

Many modern day citizen science projects are powered by mobile and web technologies, which enable the general public to take part in research and contribute to scientific knowledge around the globe $[1,2,3,5]$. The nature of these apps and web platforms vary almost as greatly as the underlying science $[6,7,8,9]$, and so do the ways in which participants interact with their mobile devices and with other participants.

A systematic search of citizen science projects conducted by Pocock et al. [10] found 509 projects that fit the definition of environmental and ecological citizen science, of which $77 \%$ were focused on biodiversity rather than the abiotic environment, and 93\% invited volunteers purely to contribute data, as opposed to taking a collaborative or co-created project approach. Of those 509 projects, 142 requested the submission of a photo as the core data type, 62 projects were found to require a smartphone for their execution, and 5 made use of SMS messaging. 
Mobile applications to support environment and biodiversity monitoring are most commonly used to record the presence and location of native and invasive species, to date and geo-reference different biological events such as reproduction, and to identify patterns of land or seabed cover [11,8].

In order to be successful, most citizen science projects require a sufficient number of participants over an extended period of time. Furthermore, the ability to meet the goals of the project will depend on the usability of the mobile application from the user's perspective, its effectiveness in carrying its purpose out from the research perspective, and whether the project itself is able to communicate and disseminate the apps and web platform to the public and sustain their engagement for a sufficiently long period of time.

Each of these factors present a range of unique challenges and pitfalls to be taken into consideration when designing and building the mobile application and web platform.

To the best of our knowledge, there is no systematic exchange of experience, knowledge, and gaps-to-beaddressed for the development of such mobile apps and web platforms for citizen science. We therefore asked citizen science practitioners and project managers to identify key considerations for the effective development of mobile applications and their adherent web platforms. We did this by way of two workshops on the topic of "Defining Principles for Apps and Platform Development for Citizen Science" that were held in Berlin on the 13th and 14th of December, 2016, and in Gothenburg on the 25th to 27th of April, 2017, in which a total of 75 practitioners took part in person or online.

This chapter summarises the outcomes of these workshops and online contributions, wherein we highlight a number of considerations for the designing, building and development of effective and sustainable applications for environmental and biodiversity mobile-based citizen science projects. The definitions of the terminology that we use in this chapter were discussed during the workshops and agreed upon among participants (Figure 1).

In this chapter, the factors that we deem important to consider and plan for at the outset of the design and build phase are described in 1) Interoperability. The factors that influence the usability of the mobile application are covered in both 2) Participant Centred Design and Agile Development, and 3) User Interface \& Experience Design. Finally, the factors that influence sustained engagement in the project are covered in 4) Motivational Factors for Participation.

App: "a self-contained program or piece of software designed to fulfil a particular purpose. It is an application, especially as downloaded by a user to a mobile device." (Oxford English Dictionary)

Citizen science: the collection and analysis of data relating to the natural world by members of the general public, in partnership with scientists and researchers, in aid of scientific research.

Citizen science participant / citizen scientist: a member of the general public who does not necessarily have scientific training, who takes part in a citizen science project on a voluntary basis.

Citizen science practitioner: anyone involved in the active development of citizen science, e.g. researcher/scientist, project manager, technical person, science communication professionals, educators, volunteer contributor, authorities, institutions, NGOs, etc.

Data: information collected in an electronic format that can be stored and used by a computer.

Forking / Software Fork: to develop a new variant of the software on the same code basis but often with an entirely new branding.

Platform: a (computing) platform is a technical framework on which one or more applications may be run and where data are kept. For the purposes of user interaction (UI) and user experience (UX), the term "website" instead of platform will be used.

Portal: web-site providing access or links to other sites. Here, especially pointing to apps, platforms, projects etc.

Figure 1: List of terminology used in this chapter. Definitions were agreed upon among workshop participants. 


\section{Interoperability}

Interoperability can refer to the ability of humans and machines to pass information between each other via shared terminology and semantic metadata [12], or to the ability of computer systems or software to exchange information between each other and make use of that information [13].

In this chapter we focus on systems interoperability, but recognise that shared terminology (which can range as widely as citizen science, crowdsourcing, citizen engagement, public participation in science, voluntary mapping, and more) between practitioners in the field, and between participants and project initiators is equally vital. Unifying these terms aids the sharing of knowledge and emerging best practice amongst those developing apps for citizen science immensely [14]. Semantics is even more important in conversations between humans and machines, or between machines [15].

\subsection{Data and Metadata Standards}

A common or interoperable structure and representation for data and metadata is needed in order to ensure that data can be shared and aggregated with other current and future projects. Such (meta)data includes information about citizen science projects, datasets, tools used (software, hardware, apps, instruments, sensors), and (domain specific) observations made by participants. Different organisations use different software solutions to organize knowledge gathered in or used by citizen science projects. These solutions can facilitate or impede interoperability. A number of existing data standards and metadata schemas that are used in citizen science projects are presented in Table 1. More schemas and their documentation can, for example, be found at schema.org. 
Table 1: Existing data and metadata standards and schemas related to citizen science

\begin{tabular}{|c|c|c|}
\hline Name & Host & Description \\
\hline DOI & - & $\begin{array}{l}\text { Digital Object Identifier: provides a system for the identification and hence } \\
\text { management of information ("content") on digital networks, providing persistence } \\
\text { and semantic interoperability. URL: doi.org }\end{array}$ \\
\hline Dublin Core & $\begin{array}{l}\text { The Dublin } \\
\text { Core Metadata } \\
\text { Initiative } \\
\text { (DCMI) }\end{array}$ & $\begin{array}{l}\text { An interoperable online metadata standard focused on networked resources. URL: } \\
\text { dublincore.org }\end{array}$ \\
\hline EML & - & $\begin{array}{l}\text { Ecological Metadata Language is a specification developed for the ecology } \\
\text { discipline. URL: knb.ecoinformatics.org }\end{array}$ \\
\hline INSPIRE & $\mathrm{EU}$ & $\begin{array}{l}\text { The EU INSPIRE Directive aims to create a Europewide infrastructure for public } \\
\text { sector spatial information. By making spatial data more interoperable, it facilitates } \\
\text { unified policies between regions, for example on the environment. To this end it } \\
\text { specifies formats and discovery services that public authorities must use for } \\
\text { publishing spatial data. URL: inspire.ec.europa.eu }\end{array}$ \\
\hline $\begin{array}{l}\text { ISO 19115- } \\
1: 2014- \\
\text { Geographic } \\
\text { information- } \\
\text { Metadata }\end{array}$ & ISO & $\begin{array}{l}\text { This metadata standard defines how to describe geographical information and } \\
\text { associated services, including contents, spatial-temporal purchases, data quality, } \\
\text { access and rights to use. It is maintained by the ISO/TC } 211 \text { committee. URL: } \\
\text { iso.org/standard/53798.html and } \\
\text { CatalogueDetailPage.CatalogueDetail?CSNUMBER }=26020\end{array}$ \\
\hline $\begin{array}{l}\text { ISO/IEC } \\
11179\end{array}$ & & $\begin{array}{l}\text { Describes the metadata and activities needed to manage data elements in a registry } \\
\text { to create a common understanding of data across organizational elements and } \\
\text { between organizations. URL: en.wikipedia.org/wiki/ISO/IEC_11179 }\end{array}$ \\
\hline MIxS & $\begin{array}{l}\text { Genomic } \\
\text { Standards } \\
\text { Consortium }\end{array}$ & $\begin{array}{l}\text { The GSC family of minimum information standards (checklists)-Minimum } \\
\text { Information about any (x) Sequence (MIxS) MIxS currently consists of three } \\
\text { separate checklists; MIGS for genomes,a MIMS for metagenomes, b and } \\
\text { MIMARKSc for marker genes. We created an overarching framework, the MIxS } \\
\text { standard.d MIxS includes the technology-specific checklists from the previous } \\
\text { MIGS and MIMS standards, provides a way of introducing additional checklists } \\
\text { such as MIMARKS, and also allows annotation of sample data using environmental } \\
\text { packages. The three checklists that are currently under MIxS share the same central } \\
\text { set of core descriptors, but have checklist specific descriptors as well. Additionally, } \\
\text { they enable a detailed description of environment through the use of optional } \\
\text { environmental packages. URL: gensc.org/mixs }\end{array}$ \\
\hline $\begin{array}{l}\text { OGC } \\
\text { SWE4CS }\end{array}$ & $\begin{array}{l}\text { Open Geospatial } \\
\text { Consortium } \\
(\text { OGC) }\end{array}$ & $\begin{array}{l}\text { Sensor Web Enablement for Citizen Science (SWE4CS) is a new standard being } \\
\text { proposed by the Citizen Science Working Group for observations, measurements } \\
\text { and sensing procedures as part of its standard suite to support sensor networks. } \\
\text { URL: portal.opengeospatial.org/ files/?artifact_id=70328 }\end{array}$ \\
\hline $\begin{array}{l}\text { Project Open } \\
\text { Data Metadata } \\
\text { Schema } \\
\text { (POD) v1.1 }\end{array}$ & $\begin{array}{l}\text { U.S. } \\
\text { Government }\end{array}$ & $\begin{array}{l}\text { A DCAT based vocabulary for metadata about data and APIs, as defined for federal } \\
\text { agencies in the US. URL: project-open-data.cio.gov/v1.1/schema }\end{array}$ \\
\hline $\begin{array}{l}\text { PPSR } \\
\text {-CORE }\end{array}$ & CitSci.org & $\begin{array}{l}\text { Public Participation in Scientific Research_Core is a standard to share basic } \\
\text { information across databases that catalog citizen science projects. It has been } \\
\text { developed in } 2013 \text { by DataONE. URL: } \\
\text { citsci.org/cwis438/websites/citsci/PPSR_Core_Documentation.php }\end{array}$ \\
\hline
\end{tabular}




\subsection{Data Sharing and Access}

In order to aid data sharing across scientific applications, research projects and academic papers, a universally unique identifier (UUID) is assigned to each observation or data point in order to avoid duplication in global databases (such as GBIF $^{1}$ ), and to be uniquely identified without significant central coordination.

After following a data model or schema as described in Table 1, we recommend that the data is made available to other researchers via a data service, most usually on the web via an Application Programming Interface (API). A range of standards are available for this purpose. Some are more complex and have a high learning curve but capture a rich set of diverse use cases (thus allowing for a high degree of interoperability). Examples of more lightweight alternatives come from within the Web Services of the Open Geospatial Consortium (OGC) and include the Web Feature Service ${ }^{2}$ or the Sensor Web Enablement suite of standards ${ }^{3}$. These cover less rich structures but are more easy to learn and apply. Another example outside the OGC is the recently revised Semantic Sensor Network (SSN) ontology of the World Wide Web Consortium (W3C)4, which may for example be queried via SPARQL 5 , a dedicated language to query information sources following the Linked Data paradigm [16].

\subsection{Data Sharing with Participants}

Two very important principles for any citizen science project, as stated in the ECSA 10 Principles of Citizen Science $^{6}$, are a) that citizen scientists receive feedback from the project in terms of how their data are being used and what the research, policy or societal outcomes are (Principle Four), and b) that project data and metadata are made publicly available and where possible, results are published in an open access format (Principle Seven).

It is therefore vital that project initiators plan for the sharing of both data and outcomes when establishing the project communication channels, with the participants of the project in mind, not just fellow researchers and scientists in the relevant fields. Both data and outcomes should be presented in a format that is easy for participants to navigate and understand.

Pocock et al. [10] found that mass participation projects were more likely to present their data dynamically (e.g. in real time rather than in summary reports) and in an elaborate format, whereas simple projects and entirely computer-based projects were less likely to make data available to view and download at a high resolution (e.g. full dataset, rather than data summaries or reports).

Indirect ways to make data and metadata available to participants are overarching portals such as EMODnet ${ }^{7}$, the GEOSS portal $^{8}$, or GBIF ${ }^{9}$ - all of which provide full and open access to observation data sets.

\subsection{Open Data and Licensing}

Open data licenses, such as those from the Creative Commons shown in Table 2 allow for the reuse of data, and can take different countries' regulations into account when a project is global or multi-national in scope. Among the Creative Commons licenses, GBIF recommends the use of "No rights reserved" (CC0), CC-BY, or CC-BY-NC. Other formats such as the Open Data Commons licenses are particularly well suited for data licensing in a citizen science context, as pointed out by Groom et al. [17], because the Creative Commons licenses were designed with creative content in mind.

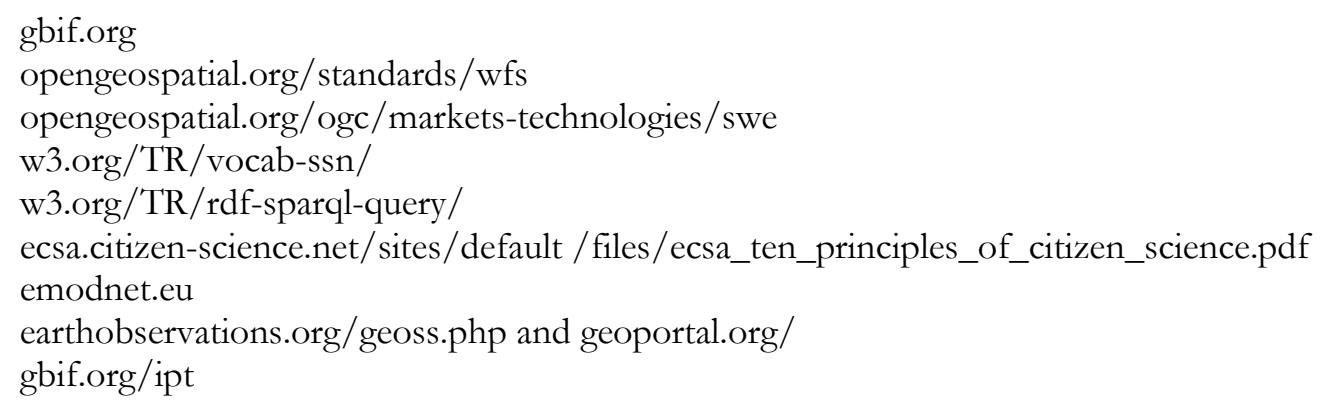


Table 2: Creative Commons (CC) and Open Data Commons (ODC) Licenses. The abbreviations in the table mean BY: Attribution, SA: Share-Alike, NC: Non-Commercial, ND: No Derivatives, ODC-PDDL: Open Data Commons Public Domain Dedication and Licence, ODC-By: Open Data Commons Attribution Licence. Source: https://creativecommons.org and Groom et al. (2016)[17].

\begin{tabular}{|l|l|l|}
\hline License Type & Abbreviation & \multicolumn{1}{c|}{ Description } \\
\hline Attribution & $\begin{array}{l}\text { CC BY and ODC- } \\
\text { By }\end{array}$ & $\begin{array}{l}\text { "This license lets others distribute, remix, tweak, } \\
\text { and build upon your work, even commercially, as } \\
\text { long as they credit you for the original creation." } \\
\text { "This license lets others remix, tweak, and build } \\
\text { upon your work even for commercial purposes, } \\
\text { as long as they credit you and license their new } \\
\text { creations under the identical terms." }\end{array}$ \\
\hline Attribution Share Alike & CC BY-SA & $\begin{array}{l}\text { "This license lets others remix, tweak, and build } \\
\text { upon your work non-commercially, and although } \\
\text { their new works must also acknowledge you and } \\
\text { be non-commercial, they don't have to license } \\
\text { their derivative works on the same terms." }\end{array}$ \\
\hline Attribution-NonCommercial & CC BY-NC & $\begin{array}{l}\text { "This license allows for redistribution, } \\
\text { commercial and non-commercial, as long as it is } \\
\text { passed along unchanged and in whole, with } \\
\text { credit to you." }\end{array}$ \\
\hline $\begin{array}{l}\text { Attribution-NonCommercial- } \\
\text { ShareAlike }\end{array}$ & CC BY-NC-SA & $\begin{array}{l}\text { "This license lets others remix, tweak, and build } \\
\text { upon your work non-commercially, as long as } \\
\text { they credit you and license their new creations } \\
\text { under the identical terms." }\end{array}$ \\
\hline $\begin{array}{l}\text { Attribution-NonCommercial- } \\
\text { NoDerivs }\end{array}$ & CC BY-NC-ND & $\begin{array}{l}\text { "This license is the most restrictive of our six } \\
\text { main licenses, only allowing others to download } \\
\text { your works and share them with others as long as } \\
\text { they credit you, but they can't change them in } \\
\text { any way or use them commercially." }\end{array}$ \\
\hline
\end{tabular}

\subsection{Software Reuse}

Existing apps can be reused for biodiversity monitoring when requiring little customization, avoiding the need to create a new application from scratch. Examples that offer an excellent solution are iNaturalist, Natusfera or iSpot (see Table 3 at the endo of this document for more examples).

Another option is to use platforms that have been built to support multiple mobile-based projects, such as the Spotteron ${ }^{10}$ platform service for fully-customisable smartphone applications for citizen science, or the Epicollect $5^{11}$ platform for creating bespoke mobile questionnaires with data mapping on a hosted website.

Yet one of the challenges for reusability remains the aspect of discovery. So far, no comprehensive repository of reusable mobile applications for citizen science exists. However there are several global and national citizen science project directories that are a useful source of information about the full range of projects and the tools that they use, such as:

- SciStarter (scistarter.com)

- Citizen Science Central (birds.cornell.edu/citscitoolkit/projects)

10 spotteron.net

11 five.epicollect.net 
- $\quad$ CitSci (Citsci.org)

- Scientific American (scientificamerican.com/citizen-science/)

- UK Environmental Observation Framework (ukeof.org.uk/catalogue )

- the Federal Crowdsourcing and Citizen Science Catalog (ccsinventory.wilsoncenter.org)

- Biocollect-Atlas of Living Australia (biocollect.ala.org.au )

- Bürger schaffen Wissen (buergerschaffenwissen.de)

- Citizen Science Austria (citizen-science.at)

- Schweiz Forscht (schweiz-forscht.ch)

- Iedereen een Wetenschapper (iedereenwetenschapper.nl)

\subsection{Software Reusability}

Since open source apps and platforms permit a higher level of customization and take advantage of a welldeveloped code base, it is valuable to open and share the code on a public repository e.g. GitHub. To maximise reuse, a good repository will include code documentation, requirement specifications, design specifications, test scenarios and results, lessons-learned documentation, and any other materials that will make it easy to 'fork' the code for a new project.

For example, the application Natusfera used a copy of the source code from iNaturalist and started an independent development on it, creating a distinct and separate piece of software. Therefore, Natusfera is a fork of iNaturalist, with its own database, look-and-feel, and special functionalities such as enabling project hierarchies.

Additionally, forking open code facilitates the interoperability with the original database, and contributes to the growth of the two platforms by sharing improvements to the underlying base.

\subsection{Data Management \& Data Privacy}

Data Management has become one of the central challenges to emerge with the growth of citizen science projects $[18,19]$. One important aspect of this is data privacy. Although scientists are naturally inclined to capture as much data as possible, including for the community of participants, it is better practice to capture as little personal data as possible, only meeting the minimum needs of the project.

Additionally, participants have to provide with the means to indicate how their data may or not be used or shared, and it is generally considered best practice for this to be provided as an opt-in, rather than an opt-out (See for example the UK Information Commisioner's Office Guidelines for Small Businesses collecting information about their customers ${ }^{12}$. For example, if data points will be shown on a publicly available map, it is critical that the participants understand and consent to this, as observations taken and shared may reveal home locations or other personal details, even if their user ID is anonymized.

Moreover, project managers are responsible for secure data transmission and storage. Personal data have to be deleted as soon as possible if they are not needed anymore to meet the objectives of the project. In other cases, data can be obfuscated using reliable methods that keep the data meaningful, but without disclosing details about the participant $[20,21]$.

These aspects of data management in citizen science are starting to gain attention in the literature. Bastin et al. [22] present the current state of the art regarding data management practices, schemas and tools, along with best-practice examples, and a range of open source technologies which can underpin robust and sustainable data management for Citizen Science. Additionally, Williams et al. [23] discuss how to sustain and maximize the impact of citizen science data.

12 ico.org.uk/media/for-organisations/documents/1584/pn_collecting_information_small_business_ checklist.pdf 


\subsection{Data Quality}

One unique aspect of citizen science contributed data is data quality and the connected question of trustworthiness. Therefore, in addition to standard data validation techniques, citizen science projects might also put additional effort in cross-validation data by comparing collected data to other sources such as remote sensing data [24]. Additionally, consider double bookkeeping approaches such as asking for pen and paper documentation of measurements in addition to mobile app based reporting. Comparison to other data reveals outliers and establish a general level of trust. Double bookkeeping allows to spot discrepancies in reporting and hence in potential measurement data issues. In addition, double bookkeeping is a fallback in case of malfunctions of mobile apps and data transmission and includes people without or incompatible smartphones.

\subsection{Data Policy Transparency}

Essential project information, such as how data is shared, should be made available to participants in a way that is completely transparent, but also removes friction in the user experience. For example, the Loss of the Night $\operatorname{app}^{13}$ (Table 3), had a participant contact the team asking for their data to be deleted, because this detail was buried in a "Terms and Conditions" page. This can be addressed by allowing participants to dive straight into the first project task, such as taking a photo, and providing the relevant data policy as part of the next step such as a 'Submit Photo' button with an explanation that the photograph will be made public. This has the additional benefit of lowering barriers to participation, by 'getting out of the way' of the citizen scientist who is embarking on a project task.

\section{Participant Centered Design and Agile Development}

The central aim of citizen science is to involve the general public in scientific research, therefore projects are usually designed to involve as broad a range of participants as possible $[25,26,5]$. This can increase complexity in terms of the range of participants' interests, abilities and motivation [27, 28, 32, 3, 29].

Participant centered design (or user-centred design in the context of mobile apps development in general) helps reach and involve participants [30] by involving them throughout the entire process, from concept - to design - to iterative user-testing - to shared outcomes. The early involvement of participants helps unearth issues such as ergonomic-factors and how to support the learning curve before final user testing takes place. It also allows the project to be structured for mutual benefit, for both the researchers and the participants, as well as ensuring a good user experience.

The development process of the app Naturblick ${ }^{14}$ (Table 3) is a good example of how to conduct participant centered design in citizen science. Potential participants were involved from the beginning by asking them about their interests and ideas which fed the conceptual process. During the development, iterative user-testing was conducted. The methods for the user-testing were adapted to the state of the development process, and ranged from focus groups to monitored testing situations with follow-up interviews. The issues and ideas were fed into the agile (i.e. iterative and incremental) development process, and resulted in prototypes for further testing and discussion. This process continued after releasing the app, which is crucial to the agile development process.

\section{User Interface and User Experience Design}

So far we have stressed the importance of taking interoperability and data management concerns into account at the outset of any new citizen science project, and of pursuing a participant-centred process throughout the design and build phase. In this section we now look more closely at the usability of the mobile application from the user's perspective. In mobile applications and web platforms developed for environmental and biodiversity citizen science, the user interface and the user experience are important factors to keep participants engaged and motivated [31, 32].

verlustdernacht.de

14 naturblick.naturkundemuseum.berlin 
User interface design refers to what is displayed on the mobile phone screen or website, with considerations such as choosing a clear typeface, a well-contrasted and visible colour palette, effective use of images and the placement of buttons, links or arrows.

User experience design refers to how the steps to be taken are placed in a logical flow, such that the project participants are eased through each step. Design elements need to be both effective and efficient, influencing how the participants perform certain interactions, and guiding them through the steps to be taken.

\subsection{Mobile Applications \& Websites}

It is typical for mobile phone based citizen science projects to provide both a website and a smartphone application (the app) as illustrated in Figure 2. Modern smartphones are a powerful tool for data-collection in the field, enabling citizen scientists to take measurements, document and photograph their observations, record geo-location data, and easily upload these data to a shared repository.

Crowdsourced contributions via website interfaces include entering and uploading observation data that were recorded on the mobile phone, processing and analysing data, and transcribing existing data into a digital format. Mobile and web interfaces have to be designed in a way that simplify data gathering, encourage participation by as wide a range of people as possible, and ideally increase scientific understanding as well.
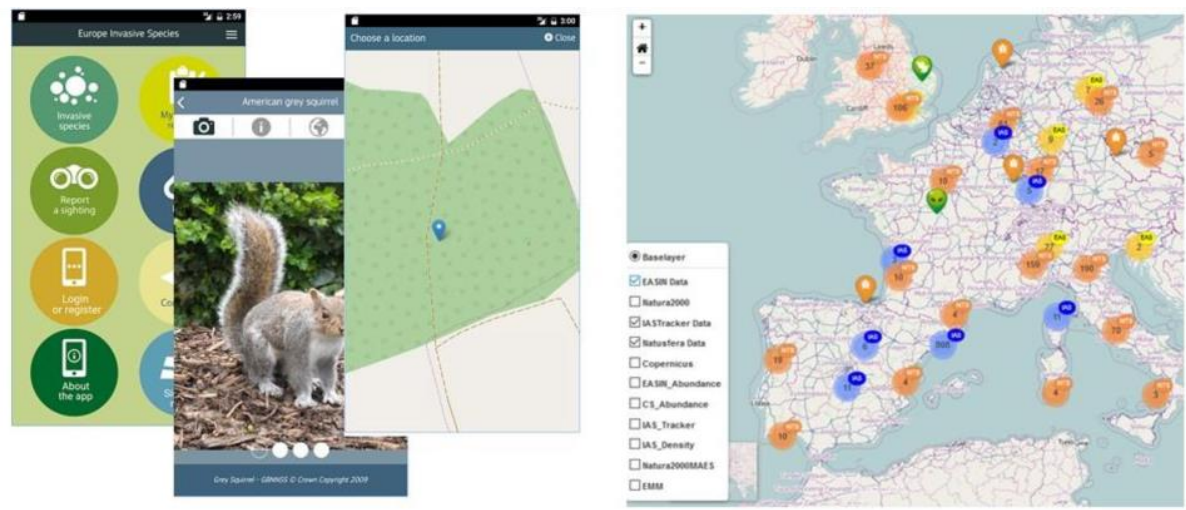

Figure 2: Examples of a mobile Citizen Science app (left), and a web page integrating gathered observations from this app and two others (right). Source: digitalearthlab.jrc.ec.europa.eu/app/invasive-alien-specieseurope.

To ensure that the interfaces are accessible to the widest possible audience, it is important to use open web standards such as the HTML5 markup language, which is ideal for cross-platform mobile applications, and to ensure that the interface and API are RESTful - i.e.based on representational state transfer (REST) technology, an architectural style and approach to communications used in web services that ensures operability, robustness, and scalability [33].

\subsection{UI/UX Best Practice in the Software Development \& Design Literature}

A brief internet search using the software development industry's shorthand of UI/UX (i.e. user interface and user experience) displays digital magazines showcasing new design trends and design patterns (e.g. Hongkiat.com, and theUXReview.co.uk), digital magazines showcasing new design element trends and winning designs (e.g. SmashingMagazine.com and UXmag.com), and indispensable tech-know-how reference books such as Effective UI: The Art of Building Great User Experience in Software [34] and Mobile First [35]. 
The mobile operating system providers also create highly useful guides for developing native applications for their platforms, such as the 'Think with Google' series on Principles of Mobile App Design 15 and the Android developer centre Design Guides ${ }^{16}$.

The primary general principle touted by most practitioners of UI/UX design is to strip the design back to the most simple functionality possible. The concept of 'Minimum Viable Product' from Lean Startup thinking refers to "that version of a new product which allows a team to collect the maximum amount of validated learning about customers with the least effort" [36], and the 'Simplicity Principle' from design thinking says that: "the design should make simple, common tasks easy, communicating clearly and simply in the user's own language, and providing good shortcuts that are meaningfully related to longer procedures" [37].

Using existing UX patterns, such as the 'hamburger' three stripes icon that indicates a menu that can be opened up for further navigation, will help project participants to feel confident that they can find their way around the app, following familiar conventions.

Another general rule of thumb for anything digital is to reduce the number of actions, or clicks, as much as possible, because user-testing consistently shows drop-off of usage with each step to be taken. This is sometimes known as the 'Three Click Rule' [38]. A further important consideration still overlooked too often is to take accessibility into account by following the Web Content Accessibility Guidelines (WCAG) ${ }^{17}$.

The key recommendation here is that sufficient time be spent perusing these useful guides to best practice in UI/UX design before embarking on the design and implementation phase of any application.

\subsection{UI/UX Considerations Specific to Citizen Science Projects}

Citizen science projects that propose to reach out to audiences with low science capital [39, 40], should conduct user-profiling to understand who is likely to use the mobile application, and in what context. For example, if the goal of the project is to reach out to school-aged children, use of language should be kept simple, and images could be used to illustrate next steps. The UCL ExCiteS group has developed the Sapelli platform ${ }^{18}$ for mobile data collection and data sharing in Citizen Science projects where the participating group are non-literate or illiterate, with little or no prior information and communications technology (ICT) experience.

Usability testing and contextual research are essential practice in this regard, allowing the project initiators to observe real users interacting with the mobile application to catch potential design improvements. An excellent case study of user testing amongst both citizen science practitioners and participants for the Creek Watch monitoring app is contained in Kim et al. [43].

"Several participants (ten environmental scientists in the City of San Jose Environmental Services Water Resources Department in a field deployment study) requested a comment field to write a description of what they were seeing. This request is particularly interesting, because none of these participants could think of a way that, as data consumers, they would have a use for this data. They simply "wanted to be able to add a little more data." The disparity between their desires as data collectors and as data consumers reinforces the value in studying both aspects of a citizen science application."

Even more importantly, testing in the field will help to uncover any 'structural' issues such as visibility of the screen in poorly lit areas, taking a photo one-handed if an object must be held simultaneously, or the importance of building data storage into your app for when the participant might be out of reception range allowing for the uploading of the data when an internet or data connection has been re-established.

Further insights into the UI/UX particularities can be found in the literature with respect to designing virtual citizen science projects [32, 41], how technology is being applied in interesting new ways [2], case studies reporting on mobile application based projects $[42,43,44]$, and best practice from the field of Human Computer Interaction (HCI) as applied to biodiversity citizen science [30].

15 thinkwithgoogle.com/marketing-resources/experience-design/principles-of-mobile-app-designintroduction/

16 developer.android.com/design/index.html

17 w3.org/WAI/intro/wcag

18 sapelli.org 


\section{Motivational Factors for Participation}

There is a great deal in the citizen science literature about the motivations to participate in projects, how to attract participants based on those motivations, and how to maintain their involvement over the longer term $[45,46]$. Because participants in citizen science are donating their time and effort freely, project initiators also have a moral obligation and duty to care for their volunteers, and to ensure that the project 'gives back' in keeping with those motivations. A good participant-centred design process will bring the relevant motivations of any given project to the foreground, which are likely to fall into one or more of the following motivational categories:

1. Learning about science $[47,46]$.

2. Making a contribution to science / collective motivations that are associated with the overall goal of the movement, including a sense of altruism [48, 47, 50].

3. Social proof of seeing that an action is valued and that others have engaged in that action / social motivations that reflect the importance of recognition by others / recognition and attribution [47, 50, 46].

4. Reward-based motivations [50].

5. Intrinsic motivations, where a participant contributes because of personal interest and enjoyment [51].

Design both the project flow of tasks and the underlying mobile app to take these motivational factors into account, including specific features to support them. This will enhance engagement at the recruitment phase, as well as over the entire length of the project [49].

\subsection{Learning about Science - Support Shared Learning}

In citizen science projects where the participant is acting independently (such as online, or with a mobile app outside the context of an organiser-led field project) learning takes place at every step, from the initial engagement with an app or platform, to actually doing the task, and beyond. Learning and communication are reciprocal (what is called two-way interaction, as is common in Bioblitz events - see [52]) and occur in tangible as well as in intangible ways. Kloetzer et al. [53] described various forms of learning and found that most learning occurs in an informal context. Therefore, the value of unstructured learning and communication has to be recognised, with space created for this to take place.

Platforms in which the community helps identifying (and validating) the observations, such as Natusfera ${ }^{19}$ (Figure 3), are a good example for how to support unstructured learning, and a powerful tool to engage untrained people who will learn progressively with the help of the community. 


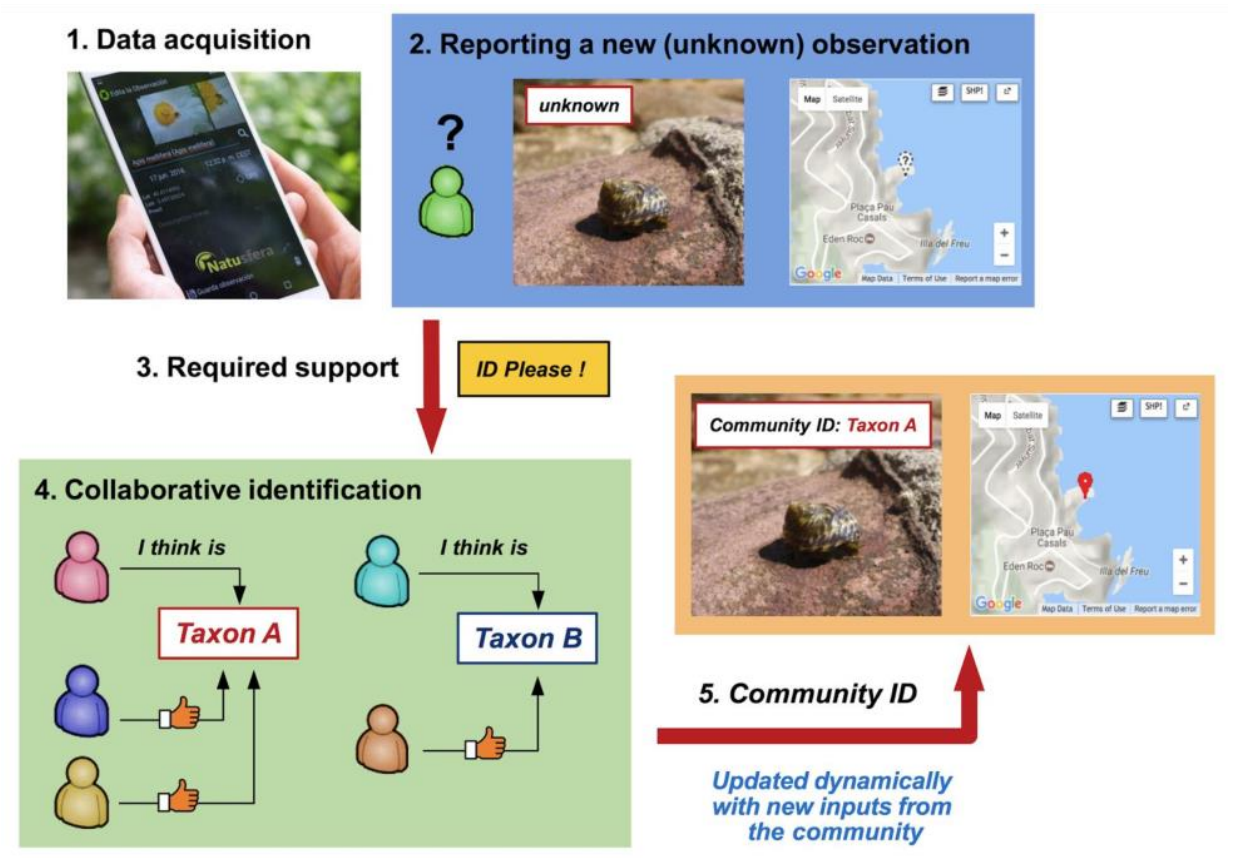

Figure 3: Schematics of how the community may help in identifying observations that the participants are not able to identify by themselves (the process can be used also to validate or correct proposed identifications).

The mobile application itself will have limited means to support learning about the object of observation or measurement in the field, but the project website can fill this gap with ongoing news updates from the project organisers, shared learning from the researchers, and signposting further information for reading and deeper understanding of the science.

\subsection{Making a Contribution to Science - Design for Two-way Communication}

News sharing channels by researchers are an important way to feel part of a bigger endeavour, but a real sense of contributing to science can only be achieved by two directions of communication - between practitioners and participants, and among participants themselves. Any citizen science project should plan for and provide two-way communication. As Jennet et al. [54] stated "It is important to provide users with tools to communicate in order to supporting social learning, community building and sharing."

Mobile applications provide a unique opportunity to embed these communications channels within the app itself, such as sending feedback to the researchers via a built-in text messaging function, or sharing notes and observations with the community via a comments function. For example, the EpiCollect ${ }^{20}$ app (Figure 4) for collecting field data via bespoke forms has embedded the Google Talk instant messenger into the app for instant field communications with the 'curator' of the project. This requires the participant to have a Gmail account, which then automatically stores transcripts for future reference [55]. 

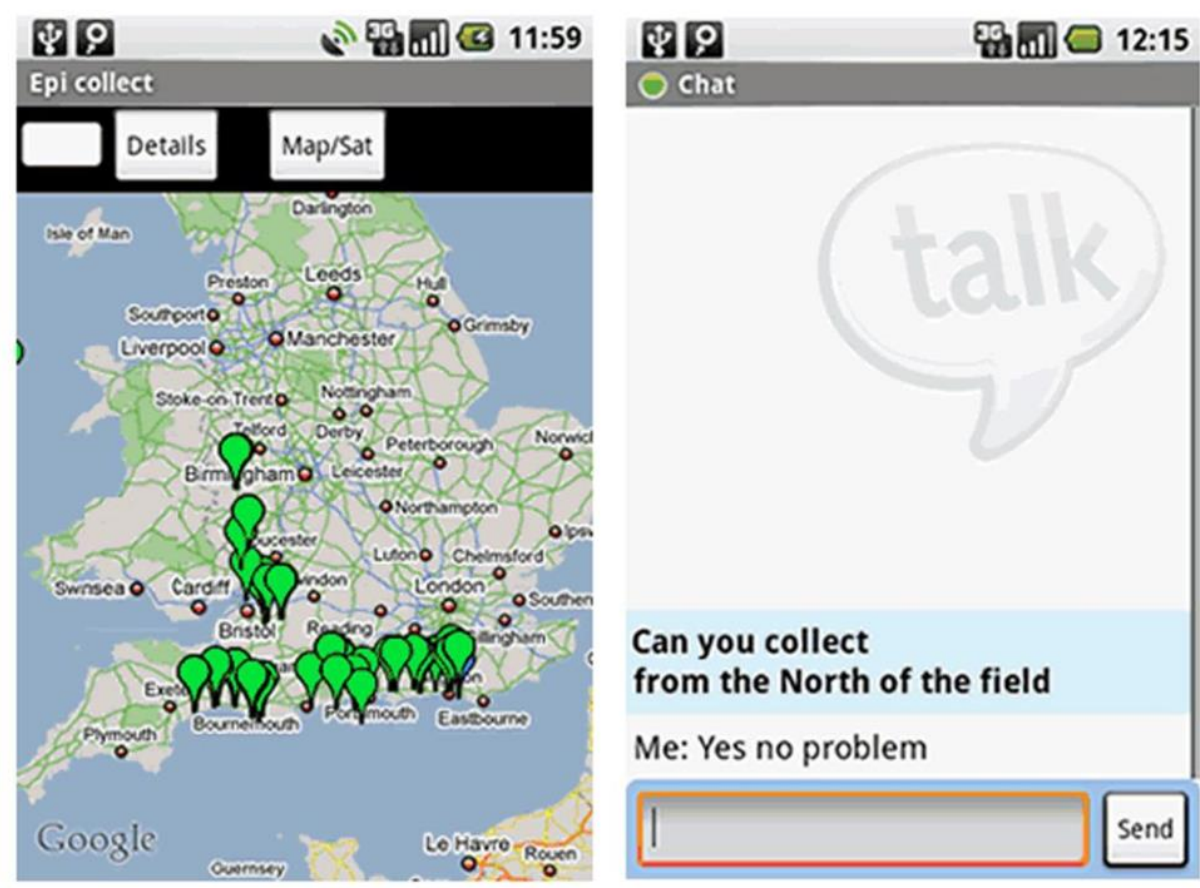

Figure : Embedded Google Talk function in EpiCollect mobile app for field data collection. (Source: journals.plos.org/plosone/article/figure?id=10.1371/journal.pone.0006968.g003).

\subsection{Social Proof - Build and Support an Active Community}

Social proof can be understood as a psychological factor that comes into play when we see evidence that other people are enjoying an activity, and that we might enjoy it too [47], but also that an activity is worthwhile doing because there is a community of people already engaged in this activity [50].

Both require visibility of the community, and for the activities of the community to be evident. Koh $e t$ al. [56] have identified offline and online interaction as key drivers for community building and collaboration:

"Leaders of robust, sustainable virtual communities find ways to strengthen their members' sense of social identity and motivate their participation in the community's activities... Understanding virtual community development provides a foundation for facilitating collaboration and learning among individuals separated by physical distance and organisational boundaries."

Social presence in physically dispersed communities can be aided by communication tools such as live text, chat and video interfaces, and also by opportunities to form stronger social bonds in person at events or group field excursions. Kim [57] suggests four factors to building sustainable communities: clear purpose or vision, clear definition of members' roles, leadership by community moderators, and online/offline events.

Online discussion forums are simple but effective means of achieving this, as well as community-oriented social media channels such as Facebook Groups. When implementing such community building tools, it is vital that a communication plan with resourcing also be in place, so that participants hear back frequently from the project initiators and researchers.

\subsection{Reward-based Motivations - Sustain Long-term Engagement}

The motives of volunteers may be different when participating in open-ended citizen science projects, and can also change over the passage of time. Long-term projects that incorporate little or no user-rewards are likely to hit a plateau in the number of users and encounter challenges in recruiting them [58].

A range of different reward systems may be considered in these cases, which focus on maximizing both the quality and quantity of the data collected, as well as on retention of volunteers. Within citizen science projects, 
these can be divided into two main types: symbolic and non-symbolic [59, 2], examples of which are shown in Table 4.

Table 4: Examples of symbolic and non-symbolic rewards

\begin{tabular}{|l|l|}
\hline Symbolic rewards & Non-symbolic rewards \\
\hline Game badges & Promotional items \\
\hline Community badges & Prizes \\
\hline Score on a leaderboard & Co-authorship on a scientific paper \\
\hline Listing of top contributors & Volunteer appreciation events \\
\hline Personal performance ratings & Payment for services \\
\hline Naming privileges & Covering expenses that are related to the activity \\
\hline Certificates & Scientific instruments and supplies \\
\hline Acknowledgement through social & \\
\hline media channels & \\
\hline
\end{tabular}

An example of different reward systems implemented in two recent campaigns run by the Geo-Wiki ${ }^{21}$ team $[60,61]$ is Picture Pile. It is a cross-platform application that is designed as a generic and flexible tool for ingesting satellite imagery for rapid classification. The application involves simple micro-tasks, where the user is presented with satellite images and is asked a simple yes/no question. Using this app, campaigns have been run with both symbolic rewards and no rewards:

- Non-symbolic rewards. In one campaign, volunteers were asked to identify the presence or absence of cropland from very high resolution satellite images and geotagged photographs. Each week, the top three players with the highest score were added to a list of weekly winners. The campaign ran for around 6 months, after which three people from the list of weekly winners were randomly drawn to win prizes, which included an e-reader, a smartphone and a tablet.

- Symbolic rewards or no rewards. In a second campaign, volunteers were asked to look at pairs of very high resolution satellite images "before" and "after" Hurricane Matthew hit Haiti to identify the presence of any visible building damage. There were no rewards although personal performance ratings and ratings on a leaderboard were provided to incentivize participation.

Both campaigns were successful in terms of the data collected, despite the different reward systems used. The difference was in the type of task undertaken by the volunteers, which attracted individuals with different underlying motivations.

\section{Discussion and Conclusions}

Apps and platforms used through mobile devices enable citizens to provide timely geospatial information that contributes to scientific understanding and decision-making for environmental and biodiversity citizen science. In this chapter, we encourage initiators of new mobile-based citizen science projects to 1) follow existing data and web standards where possible, 2) collaborate and consult with the target audience of participants early and often, 3) not reinvent the wheel, 4) build on existing UI/UX expertise regarding the development of mobile applications, and 5) factor in motivational considerations throughout.

Using accepted and well-established open standards helps to ensure reliability and interoperability with other tools. The number and range of standards is indeed vast, as only partially illustrated by Table 1, yet knowing this will provide a solid base for taking an informed decision within each specific project.

Useful guidelines, best practices and other training material to assist in the choice of standards are being worked on in the form of publications [22, 62, 23], in the context of the CSA International Working Group on Data and Metadata ${ }^{22}$, or OGC's Citizen Science Domain Working Group ${ }^{23}$.

21 geo-wiki.org

22 citizenscience.org/2015/11/12/introducing-the-data-and-metadata-working-group

23 opengeospatial.org/projects/groups/citizenscience 
Before embarking on the process of building an app and its associated website, effort needs to be made to not reinvent the wheel by looking for open source code repositories and re-usable elements of other projects. The early years of citizen science apps have seen considerable (near) reproduction of already existing apps (e.g. for noise monitoring apps shown in Table 5 at the end of this document), yet sufficient mature applications now exist, as shown in Table 3, for reuse and re-usability to become the norm.

However, it can be a challenge to find existing apps with development documentation that is thorough, upto-date, and also includes feedback (such as reporting test results user experiences). A discussion of how it can sometimes be more time consuming to re-use a ready to use tool than to build a new one can be found in the Schade et al. [19] assessment of invasive alien species apps and their potential for reuse. The need for a 'neutral' inventory (across topics) to aid the discovery and reuse of existing apps is clear. This is also exemplified in Table 5 , which provides a snapshot of the large number of noise pollution apps that have been re-created each time from scratch.

Of even more importance than the ease of re-using existing apps, source code, platforms and standards, is the fact that this can significantly lower the investment cost in terms of money, effort and expertise. It takes a professional software development approach to develop sufficiently mature applications, which is often neither in the scope of scientific projects nor accounted for in the budget planning.

There are naturally tensions between different points of view even inside the community of citizen science practitioners, with some advocating for a smaller number of platforms and systems in the name of efficiency and economies of scale; whereas others point out the need for innovation and new approaches. In this chapter we hope to have highlighted the wide range of choice available to project designers to meet the unique needs of their project and local context.

In conclusion, we highlight the general principles of citizen science, as they are expressed in the ECSA Ten Principles of Citizen Science ${ }^{24}$ as a guiding force towards best practice when designers and developers are embarking on a new citizen science project. Beyond any doubt, technology is only part of the story. New technologies open up many new possibilities, including the capacity to scale globally, yet a local focus and community-mindedness will always be needed.

\section{References}

[1] Jennett, C, Furniss, D J, Iacovides, I, Wiseman, S, Gould, S J J and Cox, A L 'Exploring Citizen PsychScience and the Motivations of Errordiary Volunteers', Human Computation 1 (2), 200-218. (2014)

[2] Newman G, Wiggins A, Crall A, Graham E, Newman S and Crowston K, The future of citizen science: Emerging technologies and shifting paradigms, Frontiers in Ecology and the Environment 10(6): 298-304, (2012) https://doi.org/10.1890/110294

[3] Raddick MJ, Bracey G, Gay PL, Lintott CJ, Cardamone C, Murray P, Galaxy Zoo: Motivations of citizen scientists, Astronomy Education Review, 12(1) (2013)

[4] Silvertown J, A new dawn for citizen science, Trends in Ecology \& Evolution 24(9): 467-471 (2009)

[5] Wiggins, A, and Crowston, K, From conservation to crowdsourcing: a typology of citizen science, In Proc. of 44th Hawaii International Conference on System Sciences (HICSS '10) (2011)

[6] Bonney, R, Shirk, JL, Phillips, TB, Wiggins, A, Ballard, HL, Miller-Rushing, AJ and Parrish, JK, Next Steps for Citizen Science, Science 343 (6178), 1436-1437 (2014)

[7] Haklay M, Citizen Science and Volunteered Geographic Information: Overview and Typology of Participation. In: Crowdsourcing Geographic Knowledge, Edited by D Z Sui, S Elwood and M F Goodchild, Dordrecht, Netherlands: Springer, 105-122 (2013)

[8] Teacher AGF, Griffiths DJ, Hodgson DJ, Inger R, Smartphones in ecology and evolution: a guide for the app-rehensive, Ecology and Evolution 3(16): 5268-5278 (2013)

[9] Pettibone L, Vohland K, Ziegler D, Understanding the (inter) disciplinary and institutional diversity of citizen science: A survey of current practice in Germany and Austria. PLoS ONE12(6): e0178778, (2017) https://doi.org/10.1371/journal.pone.0178778 
[10] Pocock MJO, Tweddle JC, Savage J, Robinson LD, Roy HE, The diversity and evolution of ecological and environmental citizen science, PLoS ONE 12(4): e0172579 (2017) https://doi.org/10.1371/journal.pone.0172579

[11] Chandler M, See L, Copas K, Bonde AMZ, Claramunt B, Danielsen F, Legind JK, Masinde S, MillerRushing AJ, Newman G, Rosemartin A, Turak E, Contribution of citizen science towards international biodiversity monitoring, Biologica Conservation (2016) http://dx.doi.org/10.1016/j.biocon.2016.09.004

[12] Sheth AP, Citizen Sensing, Social Signals, and Enriching Human Experience, IEEE Internet Computing, 13(4), 87-92 (2009) http:/ / corescholar.libraries.wright.edu/knoesis/728

[13] Ceccaroni L, Bowser A and Brenton P, Civic Education and Citizen Science: Definitions, Categories, Knowledge Representation, Analyzing the Role of Citizen Science in Modern Research, IGI Global, 1-23 (2017) [14] Eitzel MV, Cappadonna JL, Santos-Lang, Duerr RE, Virapongse A, West SE, Conrad C, Kyba M, Bowser A, Cooper CB, Sforzi A, Metcalfe AN, Harris ES, Thiel M, Haklay M, Ponciano L, Roche J, Ceccaroni L, Shilling FM, Dörler D, Heigl F, Kiessling T, Davis BY, Jiang Q, Citizen Science Terminology Matters: Exploring Key Terms. Citizen Science: Theory and Practice. 2(1), p.1. (2017) http://doi.org/10.5334/cstp.96

[15] Ceccaroni L and Piera J, Analyzing the Role of Citizen Science in Modern Research, IGI Global, 25 Oct (2016)

[16] Bizer C, Heath $\mathrm{T}$ and Berners-Lee T, Linked Data - The Story So Far, International Journal on Semantic Web and Information Systems 5(3), pp1-22 (2009).

[17] Groom Q, Weatherdon L and Geijzendorffer IR, Is citizen science an open science in the case of biodiversity observations?, Journal of Applied Ecology, 1-6 (2016) doi: 10.1111/1365-2664.12767

[18] Schade S and Tsinaraki C, Survey report: data management in Citizen Science projects, JRC Technical Report JRC101077 (2016) DOI: 10.2788/539115

[19] Schade S, Tsinaraki C and Roglia E, Scientific Data from and for the Citizen, First Monday, August 2017, Volume 22, Number 8 (2017) DOI: http://dx.doi.org/10.5210/fm.v22i8.7842

[20] Scassa T and Haewon C, Managing Intellectual Property Rights in Citizen Science: A Guide for Researchers and Citizen Scientists, Washington, DC: Woodrow Wilson International Center for Scholars (2015) http://www.wilsoncenter.org/publication-series/commons-lab

[21] Bowser A, Shilton K, Preece J, and Warrick E, Accounting for Privacy in Citizen Science: Ethical Research in a Context of Openness, In Proceedings of the 2017 ACM Conference on Computer Supported Cooperative Work and Social Computing (CSCW '17), ACM, New York, NY, USA, 2124-2136 (2017) DOI: https://doi.org/10.1145/2998181.2998305

[22] Bastin L, Schade S and Schill C (in press), Data - and metadata management for better VGI reusability. In: L. See (ed). Final book of COST Action IC1203: ENERGIC

[23] Williams $J$, et al. (in press). Citizen-science data, how should you maximise their impact and sustainability? In: Bonn A, Haklay M, Hecker S, Bowser A, Makuch Z and Vogel J (eds), Citizen Science Innovation in Open Science, Society and Policy.

[24] Schnetzer J, Kopf A, Bietz MJ, Buttigieg PL, Fernandez-Guerra A, Ristov AP, Kottmann R, MyOSD 2014: Evaluating Oceanographic Measurements Contributed by Citizen Scientists in Support of Ocean Sampling Day, Journal of Microbiology \& Biology Education, 17(1), 163-171 (2016) http://doi.org/10.1128/jmbe.v17i1.1001

[25] Bonney R, Cooper CB, Dickinson J, Kelling S, Phillips T, Rosenberg KV and Shirk J, Citizen science: A developing tool for expanding science knowledge and scientific literacy, Bioscience, 59, 11, 977-984 (2009)

[26] Rotman D, Collaborative science across the globe: The influence of motivation and culture on volunteers in the United States, India and Costa Rica, Ph.D. Dissertation, University of Maryland (2013) http://drum.lib.umd.edu/handle/1903/14163

[27] Curtis V, 'Online citizen science projects: an exploration of motivation, contribution and participation', Ph.D. thesis, The Open University (2015)

[28] Crowston K and Prestopnik NR, Motivation and Data Quality in a Citizen Science Game: A Design Science Evaluation, In: Proceedings of HICSS 2013. IEEE, pp. 450-459 (2013)

[29] Rotman D, Hammock J, Preece J, Hansen D, Boston C, Bowser A and He Y, Motivations Affecting Initial and Long-Term Participation in Citizen Science Projects in Three Countries, In: Proceedings of iConference 2014, iSchools (2014) 
[30] Preece J, Citizen Science: New Research Challenges in HCI, International Journal of Human-Computer Interaction 32, 8, 585-612 (2016) http://www.tandfonline.com/doi/full/10.1080/10447318.2016.119415

[31] Eveleigh AMM, Jennett C, Blandford A, Brohan P and Cox AL, Designing for dabblers and deterring drop-outs in citizen science. In: Proceedings of the IGCHI Conference on Human Factors in Computing Systems (CHI'14), New York, NY, U.S.A.: ACM Press, 2985-2994 (2014) DOI:10.1145/2556288.2557262

[32] Jennett C and Cox A, Eight Guidelines for Designing Virtual Citizen Science Projects, Citizen + X: Volunteer-Based Crowdsourcing in Science, Public Health, and Government: Papers from the 2014 HCOMP Workshop (2014)

[33] Fielding RT, Chapter 5: Representational State Transfer (REST), Architectural Styles and the Design of Network-based Software Architectures (Ph.D.). University of California, Irvine (2000)

[34] Anderson J, McRee J, Wilson R, Effective UI: The Art of Building Great User Experience in Software, O'Reilly Media (2010)

[35] Wroblewski L, Mobile First, A Book Apart (2011)

[36] Ries E, The Lean Startup: How Today's Entrepreneurs Use Continuous Innovation to Create Radically Successful Businesses, Crown Business, New York (2011)

[37] Bieller E, How To Design A Mobile App Using User Interface Design Principles, 06 September, Career Foundry Blog (2016) https:// careerfoundry.com/en/blog/ui-design/how-to-design-a-mobile-app-using-userinterface-design-principles/

[38] Zeldman J, Taking Your Talent to the Web: A Guide for the Transitioning Designer, New Riders Publishing (2001)

[39] Edwards R, Phillips TB, Bonney R and Mathieson K, Citizen Science and Science Capital, Stirling: University of Stirling (2015)

[40] Conrad CC and Hilchey KG, A review of citizen science and community-based environmental monitoring: issues and opportunities, Environmental Monitoring and Assessment 176: 273 (2011) https://doi.org/10.1007/s10661-010-1582-5

[41] Yadav P and Darlington J, Design Guidelines for the User-Centred Collaborative Citizen Science Platforms. Human Computation 3:1:205-211 (2016)

[42] Maisonneuve N, Stevens M, Niessen ME, Steels L, NoiseTube: Measuring and mapping noise pollution with mobile phones, In: Athanasiadis IN, Rizzoli AE, Mitkas PA, Gómez JM (eds) Information Technologies in Environmental Engineering, Environmental Science and Engineering, Springer, Berlin, Heidelberg (2009)

[43] Kim S, Robson C, Zimmerman T, Pierce J and Haber E, Creek Watch: Pairing Usefulness and Usability for Successful Citizen Science, CHI 2011, May 7-12, Vancouver, BC, Canada (2011)

[44] Traynor B, Lee T, Duke D, Case Study: Building UX Design into Citizen Science Applications, In: Marcus A, Wang W (eds) Design, User Experience, and Usability: Understanding Users and Contexts, DUXU 2017, Lecture Notes in Computer Science, vol 10290 Springer, Cham (2017)

[45] Mueller M, Tippins D and Bryan L, The future of citizen science. Democracy \& Education 20(1): 1-12 (2012)

[46] Rotman D, Preece J, Hammock J, Procita K, Hansen D, Parr C, Lewis D and Jacobs D, Dynamic changes in motivation in collaborative citizen-science projects, In: Proceedings of CSCW 2012, ACM Press, 217-226 (2012)

[47] Lee, Miller and Crowston, Recruiting Messages Matter: Message Strategies to Attract Citizen Scientists, CSCW '17 Companion, February 25 - March 01, 2017, Portland, OR, USA (2017) http://dx.doi.org/10.1145/3022198.3026335

[48] Land-Zandstra A, Devilee J, Snik F, Buurmeijer F, and van den Broek J, Citizen science on a smartphone: Participants' motivations and learning, Public Understanding of Science, Vol 25, Issue 1, 45 - 60 (2015)

[49] Nov O, Ofer A and David A, Technology-Mediated Citizen Science Participation: A Motivational Model, ICWSM (2011)

[50] Klandermans B, Collective political action, Oxford handbook of political psychology: 670-709 (2003)

[51] Geoghegan H, Dyke A, Pateman R, West S and Everett G, Understanding motivations for citizen science, Final report on behalf of UKEOF, University of Reading, Stockholm Environment Institute (University of York) and University of the West of England (2016) 
[52] Jennett C, Cognetti E, Summerfield J and Haklay M, Usability and interaction dimensions of participatory noise and ecological monitoring, In Participatory Sensing, Opinions and Collective Awareness, 201-212, Springer International Publishing (2017)

[53] Kloetzer L, Schneider D, Jennett C, Iacovides I, Eveleigh A, Cox AL, Gold M, Learning by volunteer computing, thinking and gaming: What and how are volunteers learning by participating in Virtual Citizen Science? ESREA 2013, Germany (2013)

[54] Jennett C, Kloetzer L, Schneider D, Iacovides I, Cox AL, Gold M, Fuchs B, Eveleigh A, Mathieu K, Ajani Z and Talsi Y, Motivations, learning and creativity in online citizen science, Journal of Science Communication 15 (3) (2016)

[55] Aanensen DM, Huntley DM, Feil EJ, and Spratt BG, EpiCollect: linking smartphones to web applications for epidemiology, ecology and community data collection, PloS one, 4(9), e6968 (2009)

[56] Koh J, Kim A, Butler B and Bock G, Encouraging Participation in Virtual Communities, Communications of the ACM, Vol.50. No. 2 (2007)

[57] Kim A, Community Building on the Web, Peachpit Press, Berkeley, CA (2000)

[58] Sullivan BL, Wood CL, Iliff MJ, Bonney RE, Fink D and Kelling S, eBird: A citizen-based bird observation network in the biological sciences, Biological Conservation, Elsevier BV (2009) https://doi.org/10.1016/j.biocon.2009.05.006

[59] Wiggins A, Crowdsourcing Scientific Work: A Comparative Study of Technologies, Processes, and Outcomes in Citizen Science, The School of Information Studies- Dissertations, Paper 72 (2012)

[60] Danylo O, Sturn T, Giovando C, Moorthy I, Fritz S, See L, Kapur R, Girardot B, Ajmar A, Giulio Tonolo F, Reinicke T, Mathieu P and Duerauer M, Picture Pile: A citizen-powered tool for rapid post-disaster damage assessments, Geophysical Research Abstracts, Vol. 19, EGU2017-19266, 2017 EGU General Assembly 2017 (2017)

[61] Sturn T, Wimmer M, Salk C, Perger C, See L, and Fritz S, Cropland Capture - A Game for Improving Global Cropland Maps, In: Foundatoins of Digital Games, 22-25 June 2015, California (2015)

[62] Bastin L, Schade S and Mooney P, Standards, encodings and tools for assessing fitness-for purpose, In: Bordogna, G. and P. Carrara (eds.), Mobile information Systems leveraging Volunteered Geographic Information for Earth Observation, Springer (in press)

[63] Radicchi A, Hush City app. In Invisible Places, Proceedings of the International Conference on Sound, Urbanism and the Sense of Place (in press - expected Fall 2017) 
Please cite this paper as: Luna, S., Gold, M., Albert, A., Ceccaroni, L., Claramunt, B., Danylo, O., Haklay, M., Kottmann, R., Kyba, C., Piera, J., Radicchi, A., Schade, S., and Sturm, U., 2018. Developing mobile applications for environmental and biodiversity citizen science: considerations and recommendations. In: Joly A., Vrochidis S., Karatzas K., Karppinen A., Bonnet P. (eds) Multimedia Tools and Applications for Environmental \& Biodiversity Informatics. (pp. 9-30) Springer, Cham

Table 3: List of apps, platforms and their functionalities. This list was put together for this chapter. Take in account that such a list can become obsolete in time, however it provides references and ideas that may ease the discovery of more updated lists or tools.

\begin{tabular}{|c|c|c|c|c|c|c|c|}
\hline $\begin{array}{l}\text { Name } \\
\& \text { date of } \\
\text { release } \\
\text { (tentative) }\end{array}$ & Target & Aim & (Main) functions & Scale & Holder & $\begin{array}{c}\text { Link App Store and/or Play } \\
\text { Store }\end{array}$ & $\begin{array}{l}\text { Link more } \\
\text { information }\end{array}$ \\
\hline $\begin{array}{l}\text { iNaturalist.org } \\
2008\end{array}$ & All ages & $\begin{array}{l}\text { Biodiversity } \\
\text { monitoring }\end{array}$ & $\begin{array}{l}\text { Record location and option } \\
\text { to } \\
\text { obscure it from the public, } \\
\text { record photo or sound, } \\
\text { community interaction }\end{array}$ & Worldwide & $\begin{array}{l}\text { California } \\
\text { Academy } \\
\text { of } \\
\text { Sciences }\end{array}$ & $\begin{array}{l}\text { play.google.com/store/apps } \\
\text { /details?id=org. } \\
\text { inaturalist.android and itunes. } \\
\text { apple.com/us/app/inaturalist } \\
\text { /id421397028?mt }=8\end{array}$ & inaturalist.org \\
\hline Natusfera & All ages & $\begin{array}{l}\text { Biodiversity } \\
\text { monitoring }\end{array}$ & $\begin{array}{l}\text { Record location, photo and } \\
\text { sound, community } \\
\text { interaction }\end{array}$ & Worldwide & $\begin{array}{l}\text { CREA, GBIF } \\
\text { Spain and } \\
\text { CSIC }\end{array}$ & $\begin{array}{l}\text { play.google. com/store/apps/ } \\
\text { details?id=org. } \\
\text { gbif.inaturalist.android }\end{array}$ & natusfera.gbif.es \\
\hline iSpot 2008 & All ages & $\begin{array}{l}\text { Biodiversity } \\
\text { monitoring }\end{array}$ & $\begin{array}{l}\text { Record location and photo, } \\
\text { community interaction, } \\
\text { reputation system to motivate } \\
\text { and reward participants }\end{array}$ & Worldwide & $\begin{array}{l}\text { The Open } \\
\text { University }\end{array}$ & - & ispotnature.org \\
\hline $\begin{array}{l}\text { Naturblick } \\
2016\end{array}$ & All ages & $\begin{array}{l}\text { Biodiversity } \\
\text { monitoring }\end{array}$ & $\begin{array}{l}\text { Record location, date, images } \\
\text { and sounds for species } \\
\text { identification }\end{array}$ & $\begin{array}{l}\text { Local: city } \\
\text { of Berlin }\end{array}$ & $\begin{array}{l}\text { Natural } \\
\text { History } \\
\text { Museum } \\
\text { Berlin }\end{array}$ & $\begin{array}{l}\text { play.google.com/store/apps/ } \\
\text { details?id=com.-- } \\
\text { mfn_berlin_stadtnatur_- } \\
\text { entdecken.naturblick \&hl=de } \\
\text { and itunes.apple.com/de/app/ } \\
\text { naturblick/ } \\
\text { id1206911194?mt=8\&hl=de }\end{array}$ & $\begin{array}{l}\text { naturblick. } \\
\text { naturkundemuse } \\
\text { um. } \\
\text { berlin/ }\end{array}$ \\
\hline
\end{tabular}




\begin{tabular}{|c|c|c|c|c|c|c|c|}
\hline MedMIS 2013 & All ages & $\begin{array}{l}\text { Marine } \\
\text { invasive } \\
\text { alien species } \\
\text { (IAS) } \\
\text { monitoring }\end{array}$ & $\begin{array}{l}\text { collects location, picture and } \\
\text { reports are displayed in a map }\end{array}$ & $\begin{array}{l}\text { Regional: } \\
\text { Mediterrane } \\
\text { an } \\
\text { Sea }\end{array}$ & IUCN & $\begin{array}{l}\text { itunes.apple. } \\
\text { com/en/app/iucn-medmis/ } \\
\text { id740440970?l=es\& } \\
\text { ls=1\&mt=8 and play.google. } \\
\text { com/store/apps/details? } \\
\text { id=com.geographica.iucn } \\
\text { _reporting\&hl=en }\end{array}$ & iucn-medmis.org \\
\hline Korina 2010 & All ages & $\begin{array}{l}\text { Invasive } \\
\text { alien } \\
\text { plant species } \\
\text { monitoring }\end{array}$ & $\begin{array}{l}\text { collects location, picture and } \\
\text { reports are displayed in a map }\end{array}$ & $\begin{array}{l}\text { Local: } \\
\text { Sachsony } \\
\text { Anhalt }\end{array}$ & UfU eV. & $\begin{array}{l}\text { play.google.com/store/ } \\
\text { apps/details?id=de. } \\
\text { korina\&hl=de } \\
\text { itunes.apple.com/de/ } \\
\text { app/korina/ id868783957?mt=8 }\end{array}$ & korina.info \\
\hline $\begin{array}{l}\text { Invasive Alien } \\
\text { Species in } \\
\text { Europe } 2017\end{array}$ & $\begin{array}{l}\text { General } \\
\text { public } \\
\text { (amateurs } \\
\text { and } \\
\text { profession } \\
\text { als) }\end{array}$ & $\begin{array}{l}\text { Informing } \\
\text { about } \\
\text { invasive } \\
\text { alien invasive } \\
\text { species, and } \\
\text { helping the } \\
\text { early } \\
\text { detection } \\
\text { and } \\
\text { monitoring } \\
\text { thereof. }\end{array}$ & $\begin{array}{l}\text { Receive and share } \\
\text { information } \\
\text { about Invasive Alien Species } \\
\text { (IAS) in Europe.a The app } \\
\text { provides details about } 37 \\
\text { difference IAS that are } \\
\text { considered to be of interest } \\
\text { to the complete European } \\
\text { Union. Users can record } \\
\text { pictures of possible Invasive } \\
\text { Alien Species together with } \\
\text { complementary information } \\
\text { about their observation. }\end{array}$ & $\begin{array}{l}\text { European } \\
\text { Union }\end{array}$ & $\begin{array}{l}\text { European } \\
\text { Commission }\end{array}$ & $\begin{array}{l}\text { itunes.apple.com/it/ } \\
\text { app/invasive-alien-species-in/ } \\
\text { id1117811993?mt=8 and } \\
\text { play.google. com/store/apps/ } \\
\text { details?id=eu.europa.publications.m } \\
\text { ygeossias\&hl=en }\end{array}$ & $\begin{array}{l}\text { digitalearthlab. } \\
\text { jrc.ec.europa.eu/ } \\
\text { app/invasive- } \\
\text { alien } \\
\text {-species-europe }\end{array}$ \\
\hline $\begin{array}{l}\text { Loss of the } \\
\text { Night app } \\
2013\end{array}$ & $\begin{array}{l}12+ \\
\text { (requires } \\
\text { near and } \\
\text { far vision) }\end{array}$ & $\begin{array}{l}\text { Measure how } \\
\text { bright the sky } \\
\text { is by seeing } \\
\text { how many } \\
\text { stars are } \\
\text { visible }\end{array}$ & $\begin{array}{l}\text { Star visibility meter (via } \\
\text { human eye observations) }\end{array}$ & Worldwide & $\begin{array}{l}\text { Christopher } \\
\text { Kyba, GFZ } \\
\text { German } \\
\text { Research Centre } \\
\text { for Geosciences }\end{array}$ & $\begin{array}{l}\text { https://play.google.com/store/app } \\
\text { s/details?id=com.cosalux.welovesta } \\
\text { rs } \\
\text { https://itunes.apple.com/en/app/1 } \\
\text { oss-of-the-night/id928440562 }\end{array}$ & $\begin{array}{l}\text { http://lossofthen } \\
\text { ght.blogspot.de/2 } \\
\text { 015/01/brief- } \\
\text { introduction-to- } \\
\text { loss-of-night- } \\
\text { app.html }\end{array}$ \\
\hline $\begin{array}{l}\text { My Sky at Night } \\
2015\end{array}$ & $12+$ & $\begin{array}{l}\text { Improve } \\
\text { access to light } \\
\text { pollution data }\end{array}$ & $\begin{array}{l}\text { Visualize light pollution data } \\
\text { Evaluate accuracy of Loss of } \\
\text { the Night app observations } \\
\text { Plot trends in sky brightness } \\
\text { Download data as csv files }\end{array}$ & Worldwide & $\begin{array}{l}\text { Christopher } \\
\text { Kyba, GFZ } \\
\text { German } \\
\text { Research Centre } \\
\text { for Geosciences }\end{array}$ & - & $\begin{array}{l}\text { http:// } \\
\text { www.myskyatnigh } \\
\text { t.com/ }\end{array}$ \\
\hline
\end{tabular}




\begin{tabular}{|c|c|c|c|c|c|c|c|}
\hline $\begin{array}{l}\text { My Simulated } \\
\text { Sky at Night } \\
\text { (expected 2018) }\end{array}$ & $15+$ & $\begin{array}{l}\text { Improve } \\
\text { understanding } \\
\text { of how street } \\
\text { light } \\
\text { technology } \\
\text { impacts } \\
\text { skyglow (light } \\
\text { pollution) }\end{array}$ & $\begin{array}{l}\text { Sliders to adjust type of } \\
\text { lighting installed, generates } \\
\text { maps of sky brightness based } \\
\text { on the setting }\end{array}$ & Worldwide & $\begin{array}{l}\text { Christopher } \\
\text { Kyba, GFZ } \\
\text { German } \\
\text { Research Centre } \\
\text { for Geosciences }\end{array}$ & - & Not yet online \\
\hline Fotoquest Go & All ages & $\begin{array}{l}\text { Undertake } \\
\text { 'quests' to } \\
\text { travel to } \\
\text { specific } \\
\text { locations and } \\
\text { collect } \\
\text { information } \\
\text { on land } \\
\text { cover and } \\
\text { land use } \\
\text { based on a } \\
\text { simplified } \\
\text { LUCAS } \\
\text { protocol }\end{array}$ & $\begin{array}{l}\text { Stores the land cover /land } \\
\text { use information and } \\
\text { geotagged photographs in } \\
\text { the Geo-Wiki database } \\
\text { Provides gamification } \\
\text { functions such as a } \\
\text { leaderboard, awarding higher } \\
\text { points for quests taken the } \\
\text { first time, etc. }\end{array}$ & $\begin{array}{l}\text { Initially } \\
\text { applied to } \\
\text { Austria and } \\
\text { Europe } \\
\text { (from Sep } \\
\text { 2017) but } \\
\text { could be } \\
\text { applied } \\
\text { worldwide }\end{array}$ & $\begin{array}{l}\text { International } \\
\text { Institute for } \\
\text { Applied Systems } \\
\text { Analysis }\end{array}$ & $\begin{array}{l}\text { https://play.google.com/store/app } \\
\text { s/details?id=com.IIASA.FotoQues } \\
\text { tGo\&hl=en }\end{array}$ & $\begin{array}{l}\text { http:/ / fotoquest- } \\
\text { go.org/ }\end{array}$ \\
\hline Picture Pile & All ages & $\begin{array}{l}\text { Rapid } \\
\text { classification } \\
\text { of satellite } \\
\text { images } \\
\text { (deforestation } \\
\text {, post-disaster } \\
\text { damage } \\
\text { assessment, } \\
\text { cropland) }\end{array}$ & $\begin{array}{l}\text { Simple interface for } \\
\text { answering yes/no/maybe to } \\
\text { one classification question by } \\
\text { swiping image left, right or } \\
\text { down } \\
\text { Stores the answers to the } \\
\text { question in the Geo-Wiki } \\
\text { database } \\
\text { Provides gamification } \\
\text { functions such as } \\
\text { leaderboards }\end{array}$ & $\begin{array}{l}\text { Region and } \\
\text { case specific } \\
\text { (disaster } \\
\text { response, e.g. } \\
\text { Hurricane } \\
\text { Matthew in } \\
\text { Haiti) but } \\
\text { could also be } \\
\text { applied } \\
\text { worldwide }\end{array}$ & $\begin{array}{l}\text { International } \\
\text { Institute for } \\
\text { Applied Systems } \\
\text { Analysis }\end{array}$ & $\begin{array}{l}\text { https://play.google.com/store/app } \\
\text { s/details?id=air.PicturePile } \\
\text { https://itunes.apple.com/us/app/ } \\
\text { picture- } \\
\text { pile/id926740054?ls=1\&mt=8 }\end{array}$ & $\begin{array}{l}\text { http://geo- } \\
\text { wiki.org/games/p } \\
\text { icturepile }\end{array}$ \\
\hline
\end{tabular}




\begin{tabular}{|c|c|c|c|c|c|c|c|}
\hline $\begin{array}{l}\text { Geo-Wiki } \\
\text { Pictures }\end{array}$ & All ages & $\begin{array}{l}\text { Take geo- } \\
\text { tagged } \\
\text { photographs } \\
\text { of the } \\
\text { landscape and } \\
\text { classify the } \\
\text { land cover } \\
\text { using built-in } \\
\text { legends or via } \\
\text { a user- } \\
\text { generated } \\
\text { legend (e.g. } \\
\text { crop types) }\end{array}$ & $\begin{array}{l}\text { Stores the land cover (or } \\
\text { customized legend attributes) } \\
\text { and geotagged photographs } \\
\text { in the Geo-Wiki database } \\
\text { Geotagged photographs can } \\
\text { be displayed and managed } \\
\text { via the Geo-Wiki Pictures } \\
\text { branch (www.geo-wiki.org) }\end{array}$ & Worldwide & \begin{tabular}{|l|} 
International \\
Institute for \\
Applied Systems \\
Analysis
\end{tabular} & $\begin{array}{l}\text { https://play.google.com/store/app } \\
\text { s/details?id=GeoWikiMobile.Geo } \\
\text { WikiMobile\&hl=en } \\
\\
\text { https://itunes.apple.com/at/app/g } \\
\text { eo-wiki-mobile/id533430760 } \\
\text { https://www.microsoft.com/de- } \\
\text { de/store/p/geo-wiki- } \\
\text { picture/9nblggh4t183 }\end{array}$ & $\begin{array}{l}\text { http://geo- } \\
\text { wiki.org/branche } \\
\text { /pictures }\end{array}$ \\
\hline $\begin{array}{l}\text { LACO-Wiki } \\
\text { Mobile }\end{array}$ & All ages & $\begin{array}{l}\text { Validate land } \\
\text { cover and } \\
\text { land use } \\
\text { maps on the } \\
\text { ground }\end{array}$ & $\begin{array}{l}\text { Stores land cover / land use } \\
\text { and any geo-tagged } \\
\text { photographs in the LACO- } \\
\text { Wiki land cover validation } \\
\text { repository }\end{array}$ & $\begin{array}{l}\text { Can be } \\
\text { applied at any } \\
\text { scale from } \\
\text { local to } \\
\text { worldwide }\end{array}$ & $\begin{array}{l}\text { International } \\
\text { Institute for } \\
\text { Applied Systems } \\
\text { Analysis }\end{array}$ & $\begin{array}{l}\text { https://play.google.com/store/app } \\
\text { s/details?id=com.geomarvel.com.la } \\
\text { cowiki\&hl=en }\end{array}$ & $\begin{array}{l}\text { https://laco- } \\
\text { wiki.net }\end{array}$ \\
\hline
\end{tabular}




\begin{tabular}{|c|c|c|c|c|c|c|c|}
\hline $\begin{array}{l}\text { Noisemap } \\
2012\end{array}$ & All ages & $\begin{array}{l}\text { - Measure the } \\
\text { sound } \\
\text { exposure } \\
\text { - Tag noisy } \\
\text { sources } \\
\text { - Create a } \\
\text { collective map } \\
\text { of noise } \\
\text { pollution }\end{array}$ & Sound levels meter & Darmstadt & $\begin{array}{l}\text { Technical } \\
\text { University of } \\
\text { Darmstadt }\end{array}$ & $\begin{array}{l}\text { https://play.google.com/store/app } \\
\text { s/details?id=de.tudarmstadt.tk.nois } \\
\text { emap }\end{array}$ & $\begin{array}{l}\text { ttps://www.tk.info } \\
\text { rmatik.tu- } \\
\text { darmstadt.de/de/r } \\
\text { esearch/smart- } \\
\text { urban- } \\
\text { networks/noisema } \\
\text { p/ } \\
\text { ttp://www.da- } \\
\text { sense.de/\# }\end{array}$ \\
\hline $\begin{array}{l}\text { Noise Tube } \\
2008\end{array}$ & All ages & \begin{tabular}{|l|} 
Measure the \\
sound \\
exposure, tag \\
noisy \\
sources, \\
create a \\
collective \\
map of \\
noise \\
pollution
\end{tabular} & Sound levels meter & Worldwide & $\begin{array}{l}\text { Sony } \\
\text { Computer } \\
\text { Science Lab in } \\
\text { Paris } \\
\text { (csl.sony.fr) } \\
\text { and } \\
\text { Software } \\
\text { Languages } \\
\text { Lab at the } \\
\text { Vrije } \\
\text { Universiteit } \\
\text { Brussel } \\
\text { (soft.vub .ac.b } \\
\text { e/) }\end{array}$ & $\begin{array}{l}\text { play.google.com/store/apps/ } \\
\text { details?id=net.noisetube }\end{array}$ & $\begin{array}{l}\text { noisetube.net/in } \\
\text { dex.html\#\&pane } \\
11-1\end{array}$ \\
\hline $\begin{array}{l}\text { WideNoise } \\
2009\end{array}$ & All ages & \begin{tabular}{|l|} 
Measure the \\
sound \\
exposure, tag \\
noisy \\
sources, \\
create a \\
collective \\
map of noise \\
pollution
\end{tabular} & Sound levels meter & Worldwide & $\begin{array}{l}\text { CSP, L3S } \\
\text { Kassel / } \\
\text { Würzburg }\end{array}$ & $\begin{array}{l}\text { itunes.apple.com/app/ } \\
\text { id657693514 and } \\
\text { play.google. } \\
\text { com/store/apps/ } \\
\text { details?id=eu.everyaware. } \\
\text { widenoise.android }\end{array}$ & $\begin{array}{l}\text { cs.everyaware.eu } \\
/ \\
\text { event/ } \\
\text { widenoise/ and } \\
\text { cs.everyaware.eu } \\
/ \text { / } \\
\text { event/widenoise }\end{array}$ \\
\hline
\end{tabular}




\begin{tabular}{|c|c|c|c|c|c|c|c|}
\hline $\begin{array}{l}\text { Citclops / } \\
\text { EyeOnWater } \\
2013\end{array}$ & All ages & $\begin{array}{l}\text { An } \\
\text { observatory } \\
\text { for coast and } \\
\text { ocean optical } \\
\text { monitoring }\end{array}$ & $\begin{array}{l}\text { Several new sensor systems } \\
\text { based on optical } \\
\text { technologies, to respond to a } \\
\text { number of scientific, } \\
\text { technical and societal } \\
\text { objectives, ranging from } \\
\text { more precise monitoring of } \\
\text { key environmental } \\
\text { descriptors of the aquatic } \\
\text { environment (water colour, } \\
\text { transparency and } \\
\text { fluorescence) to an improved } \\
\text { management of data } \\
\text { collected with citizen } \\
\text { participation and } \\
\text { engagement. }\end{array}$ & Worldwide & Free & $\begin{array}{l}\text { https://itunes.apple.com/us/app/e } \\
\text { yeonwater- } \\
\text { colour/id1021542366?mt=8 } \\
\text { https://play.google.com/store/app } \\
\text { s/details?id=nl.maris.citclops.cross } \\
\text { walk }\end{array}$ & $\begin{array}{l}\text { http://www.citcl } \\
\text { ps.eu/ } \\
\text { http://www.eyeo } \\
\text { nwater.org/ }\end{array}$ \\
\hline $\begin{array}{l}\text { Ambiciti } \\
2016\end{array}$ & All ages & $\begin{array}{l}\text { - Measure the } \\
\text { sound } \\
\text { exposure } \\
\text { - Develop } \\
\text { correlation } \\
\text { with stress } \\
\text { levels } \\
\text { - Compute air } \\
\text { quality } \\
\text {-Indicate the } \\
\text { safest route to } \\
\text { your } \\
\text { destination }\end{array}$ & $\begin{array}{l}\text { Sound levels meter } \\
\text { Air quality calculation } \\
\text { software }\end{array}$ & $\begin{array}{l}\text { Worldwide, } \\
\text { Paris \& San } \\
\text { Francisco } \\
\text { (for the Air } \\
\text { Quality } \\
\text { maps) }\end{array}$ & Ambiciti & $\begin{array}{l}\text { https://play.google.com/store/app } \\
\text { s/details?id=fr.inria.mimove.quanti } \\
\text { fiedself } \\
\text { https://itunes.apple.com/us/app/a } \\
\text { mbiciti/id1080606926?mt=8 }\end{array}$ & $\begin{array}{l}\text { ttp://www.ambicit } \\
\text { i.io }\end{array}$ \\
\hline $\begin{array}{l}\text { Ocean } \\
\text { Sampling } \\
\text { Day Citizen } \\
\text { App } \\
\text { (OSD-App) } \\
2014\end{array}$ & All ages & $\begin{array}{l}\text { Genomic } \\
\text { Biodiversity } \\
\text { Observations }\end{array}$ & $\begin{array}{l}\text { Record location, photo and } \\
\text { environmental data } \\
\text { accompanying the genomic } \\
\text { sampling event of } \\
\text { Ocean Sampling Day }\end{array}$ & Worldwide & $\begin{array}{l}\text { Micro B3 } \\
\text { Consortium }\end{array}$ & $\begin{array}{l}\text { play.google.com/store/ } \\
\text { apps/details?id=com.iw.esa } \\
\text { \&hl=en (IOS version upon } \\
\text { request) }\end{array}$ & $\begin{array}{l}\text { mb3is.megx.n } \\
\text { et/osd-app }\end{array}$ \\
\hline
\end{tabular}


Please cite this paper as: Luna, S., Gold, M., Albert, A., Ceccaroni, L., Claramunt, B., Danylo, O., Haklay, M., Kottmann, R., Kyba, C., Piera, J., Radicchi, A., Schade, S., and Sturm, U., 2018. Developing mobile applications for environmental and biodiversity citizen science: considerations and recommendations. In: Joly A., Vrochidis S., Karatzas K., Karppinen A., Bonnet P. (eds) Multimedia Tools and Applications for Environmental \& Biodiversity Informatics. (pp. 9-30) Springer, Cham

Table 5: List of Apps for sonic environment and noise pollution monitoring, their functionalities and links for download and discovery

\begin{tabular}{|c|c|c|c|c|c|c|c|}
\hline $\begin{array}{l}\text { Name } \\
\& \text { date of } \\
\text { release } \\
\text { (tentative) }\end{array}$ & Target & Aim & (Main) functions & Scale & Holder & $\begin{array}{c}\text { Link App Store and/or Play } \\
\text { Store }\end{array}$ & $\begin{array}{l}\text { Link more } \\
\text { information }\end{array}$ \\
\hline $\begin{array}{l}\text { Noisemap } \\
2012\end{array}$ & All ages & $\begin{array}{l}\text { Measure the } \\
\text { sound } \\
\text { exposure } \\
\text { Tag noisy } \\
\text { sources } \\
\text { Create a } \\
\text { collective } \\
\text { map of noise } \\
\text { pollution }\end{array}$ & Sound levels meter & Darmstadt & $\begin{array}{l}\text { Technical } \\
\text { University of } \\
\text { Darmstadt }\end{array}$ & $\begin{array}{l}\text { https://play.google.com/store/app } \\
\text { s/details?id=de.tudarmstadt.tk.nois } \\
\text { emap }\end{array}$ & $\begin{array}{l}\text { https://www.tk.i } \\
\text { nformatik.tu- } \\
\text { darmstadt.de/de } \\
\text { /research/smart } \\
\text {-urban- } \\
\text { networks/noise } \\
\text { map/ } \\
\text { http://www.da- } \\
\text { sense.de/\# }\end{array}$ \\
\hline $\begin{array}{l}\text { I-SAY Sound } \\
\text { Around You } \\
2012\end{array}$ & All ages & $\begin{array}{l}\text { Record } \\
\text { sounds from } \\
\text { the } \\
\text { environment } \\
\text { Tag } \\
\text { soundscapes } \\
\text { Create a } \\
\text { collective } \\
\text { sound map }\end{array}$ & Audio recorder & $\begin{array}{l}\text { UK, } \\
\text { Worldwide }\end{array}$ & $\begin{array}{l}\text { The Audio and } \\
\text { Acoustic } \\
\text { Engineering } \\
\text { Research } \\
\text { Centre, } \\
\text { University of } \\
\text { Salford (UK) } \\
\text { http://www.ac } \\
\text { oustics.salford. } \\
\text { ac.uk/ }\end{array}$ & Not available on Google Play store & $\begin{array}{l}\text { http://www.sou } \\
\text { ndaroundyou.co } \\
\text { m }\end{array}$ \\
\hline $\begin{array}{l}\text { Soundscape } \\
\text { Characterization } \\
\text { Tool } \\
2013\end{array}$ & All ages & $\begin{array}{l}\text { Record } \\
\text { soundscapes } \\
\text { Tag } \\
\text { soundscapes }\end{array}$ & Audio recorder & Worldwide & $\begin{array}{l}\text { Per Hedfors, } \\
\text { Swedish } \\
\text { University of } \\
\text { Agricultural } \\
\text { Sciences (SLU) } \\
\text { Uppsala }\end{array}$ & $\begin{array}{l}\text { https: / /itunes.apple.com/us/app/s } \\
\text { oundscape-characterization- } \\
\text { tool/id773077497?mt }=8 \\
\text { Not available on Google Play store }\end{array}$ & / \\
\hline
\end{tabular}




\begin{tabular}{|c|c|c|c|c|c|c|c|}
\hline $\begin{array}{l}\text { radio aporee } \\
2013\end{array}$ & All ages & $\begin{array}{l}\text { Record } \\
\text { soundscapes } \\
\text { Tag } \\
\text { soundscapes } \\
\text { Create a } \\
\text { collective real } \\
\text { time sound } \\
\text { map }\end{array}$ & Audio recorder & Worldwide & Udo Noll & $\begin{array}{l}\text { https://itunes.apple.com/de/app/ } \\
\text { radio-aporee/id640921893?mt=8 } \\
\text { https://play.google.com/store/app } \\
\text { s/details?id=com.aporee.radio\&hl } \\
=\text { it }\end{array}$ & $\begin{array}{l}\text { http://aporee.or } \\
\mathrm{g} / \mathrm{maps} /\end{array}$ \\
\hline $\begin{array}{l}\text { Geluidenjager } \\
2014\end{array}$ & All ages & $\begin{array}{l}\text { Record } \\
\text { soundscapes } \\
\text { Tag } \\
\text { soundscapes } \\
\text { Create a } \\
\text { collective } \\
\text { sound map }\end{array}$ & Audio recorder & $\begin{array}{l}\text { The } \\
\text { Netherlands }\end{array}$ & $\begin{array}{l}\text { Nederlands } \\
\text { Instituut voor } \\
\text { Beeld en } \\
\text { Geluid }\end{array}$ & $\begin{array}{l}\text { https://play.google.com/store/app } \\
\text { s/details?id=net.webmapper.gvnl } \\
\text { https://itunes.apple.com/ca/app/ } \\
\text { geluidenjager/id530062802?mt=8 }\end{array}$ & $\begin{array}{l}\text { http://geluidvan } \\
\text { nederland.nl }\end{array}$ \\
\hline
\end{tabular}




\begin{tabular}{|c|c|c|c|c|c|c|c|}
\hline $\begin{array}{l}\text { Recho } \\
2014\end{array}$ & All ages & $\begin{array}{l}\text { Record } \\
\text { soundscapes } \\
\text { and } \\
\text { narratives } \\
\text { Create a } \\
\text { collective } \\
\text { hidden sound } \\
\text { map }\end{array}$ & Audio recorder & Worldwide & Recho ApS & $\begin{array}{l}\text { https://itunes.apple.com/us/app/r } \\
\text { echo/id865541527?mt=8 } \\
\text { Not available on Google Play store }\end{array}$ & http://recho.org \\
\hline $\begin{array}{l}\text { Record the Earth } \\
2014\end{array}$ & All ages & $\begin{array}{l}\text { Record } \\
\text { sounds of the } \\
\text { earth } \\
\text { Create a } \\
\text { collective } \\
\text { sound map }\end{array}$ & Audio recorder & Worldwide & $\begin{array}{l}\text { Purdue } \\
\text { University }\end{array}$ & $\begin{array}{l}\text { https://play.google.com/store/app } \\
\text { s/details?id=com.recordtheearth } \\
\text { https://itunes.apple.com/us/app/s } \\
\text { oundscape- } \\
\text { recorder/id836741158?mt=8 }\end{array}$ & $\begin{array}{l}\text { https://www.rec } \\
\text { ordtheearth.org }\end{array}$ \\
\hline $\begin{array}{l}\text { The Noise App } \\
2015\end{array}$ & All ages & $\begin{array}{l}\text { Measure the } \\
\text { sound } \\
\text { exposure } \\
\text { Report } \\
\text { complaints }\end{array}$ & Sound levels meter & Worldwide & $\begin{array}{l}\text { Noise } \\
\text { Nouisance }\end{array}$ & $\begin{array}{l}\text { https://itunes.apple.com/gb/app/ } \\
\text { the-noise-app/id926445612?mt=8 } \\
\text { https://play.google.com/store/app } \\
\text { s/details?id=com.rhe.noiseapp\&hl } \\
\text { =en_GB }\end{array}$ & $\begin{array}{l}\text { http://noisenuis } \\
\text { ance.org/the- } \\
\text { app/ } \\
\text { http://www.the } \\
\text { noiseapp.com/\# } \\
\text { / }\end{array}$ \\
\hline $\begin{array}{l}\text { Sound City* } \\
2015\end{array}$ & All ages & $\begin{array}{l}\text { Measure the } \\
\text { sound } \\
\text { exposure } \\
\text { Develop } \\
\text { correlation } \\
\text { with stress } \\
\text { levels }\end{array}$ & Sound levels meter & Worldwide & $\begin{array}{l}\text { Inria at Silicon } \\
\text { valley }\end{array}$ & Then turned into Ambiciti & $\begin{array}{l}\text { http://urbancivi } \\
\text { cs.com/soundcit } \\
\text { y_app.html }\end{array}$ \\
\hline
\end{tabular}




\begin{tabular}{|c|c|c|c|c|c|c|c|}
\hline $\begin{array}{l}\text { Aircasting } \\
2016\end{array}$ & All ages & $\begin{array}{l}\text { Record, map, } \\
\text { and share: } \\
\text { Sound levels } \\
\text { Temperature, } \\
\text { humidity, and } \\
\text { fine } \\
\text { particulate } \\
\text { matter } \\
\text { (PM2.5) } \\
\text { Temperature, } \\
\text { humidity, CO } \\
\text { and NO2 gas } \\
\text { Heart rate, } \\
\text { heart rate } \\
\text { variability, R } \\
\text { to R, } \\
\text { breathing } \\
\text { rate, activity } \\
\text { level, peak } \\
\text { acceleration, } \\
\text { and core } \\
\text { temperature } \\
\text { Heart rate }\end{array}$ & $\begin{array}{l}\text { Sound levels meter } \\
\text { Arduino-powered AirBeam } \\
\text { Arduino-powered AirCasting } \\
\text { Air Monitor } \\
\text { Zephyr BioHarness } 3 \\
\text { Zephyr HxM }\end{array}$ & Worldwide & Habitatmap & $\begin{array}{l}\text { https://play.google.com/store/app } \\
\text { s/details?id=pl.llp.aircasting\&hl=e } \\
\text { n } \\
\text { Not available on iTunes }\end{array}$ & $\begin{array}{l}\text { http:// aircasting } \\
\text {.org } \\
\text { http:// habitatma } \\
\text { p.org }\end{array}$ \\
\hline $\begin{array}{l}\text { Think About } \\
\text { Sound } \\
2015\end{array}$ & All ages & $\begin{array}{l}\text { Record } \\
\text { sounds } \\
\text { Rate the } \\
\text { sounds and } \\
\text { their impact } \\
\text { on user } \\
\text { feelings } \\
\text { Create a } \\
\text { collective 3D } \\
\text { sound map }\end{array}$ & Audio recorde & UK & $\begin{array}{l}\text { Adam Craig, } \\
\text { Glasgow } \\
\text { Caledonian } \\
\text { University }\end{array}$ & $\begin{array}{l}\text { https://itunes.apple.com/gb/app/ } \\
\text { think-about- } \\
\text { sound/id969517179?mt=8 } \\
\text { https://play.google.com/store/app } \\
\text { s/details?id=com.adamcraig.thinka } \\
\text { boutsound }\end{array}$ & $\begin{array}{l}\text { http://www.glas } \\
\text { gow3dsoundma } \\
\text { p.co.uk/soundm } \\
\text { ap.html }\end{array}$ \\
\hline
\end{tabular}




\begin{tabular}{|l|l|l|l|l|l|l|l|}
\hline $\begin{array}{l}\text { City Soundscape } \\
2016\end{array}$ & All ages & $\begin{array}{l}\text { Measure the } \\
\text { sound } \\
\text { exposure } \\
\text { Provide user } \\
\text { feedback }\end{array}$ & Sound levels meter & Puglia (Italy) & $\begin{array}{l}\text { Alba Project } \\
\text { s.r.l. }\end{array}$ & $\begin{array}{l}\text { https://play.google.com/store/app } \\
\text { s/details?id=it.albaproject.citysoun } \\
\text { dscape\&hl=it }\end{array}$ & $\begin{array}{l}\text { http://www.city } \\
\text { soundscape.it/ } \\
\text { http://www.fi- } \\
\text { frontiercities.eu/ } \\
\text { \#!City- } \\
\text { Soundscape- } \\
\text { signs-threeyear- } \\
\text { convention- } \\
\text { with-ASSTRA- } \\
\text {-Puglia- } \\
\text { Transport- } \\
\text { Association/gdb } \\
\text { tt/5731a8ba0cf2 } \\
38 \text { e05b83deee }\end{array}$ \\
\hline $\begin{array}{l}\text { MoSart } \\
2016\end{array}$ & All ages & $\begin{array}{l}\text { Record } \\
\text { sounds } \\
\text { Appraise the } \\
\text { sound of the } \\
\text { environment }\end{array}$ & Audio Recorder & Worldwide & $\begin{array}{l}\text { SoundApprais } \\
\text { al }\end{array}$ & $\begin{array}{l}\text { https://itunes.apple.com/us/app/ } \\
\text { mosart/id1110652343 } \\
\text { https://play.google.com/store/app } \\
\text { s/details?id=org.auditoryenvironm } \\
\text { ents.mosart }\end{array}$ \\
\hline
\end{tabular}

